\title{
エネルギー関数法に基づいた電力系統の オンライン過渡安定度予防制御手法
}

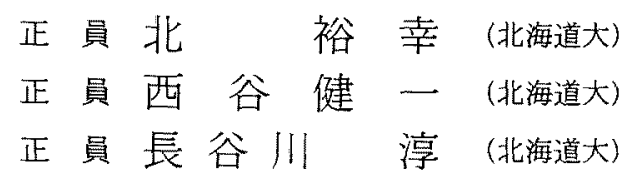

\section{On-line Preventive Control for Power System Transient Stability} Based on the Energy Function Method

\author{
Hiroyuki Kita, Member, Ken-ichi Nishiya, Member, Jun Hasegawa, Member (Hokkaido \\ University)
}

For the purpose of maintaining the power system security, the authors are developing an integrated security monitoring and control (ISMAC) system, in which both of the preventive and the emergency control basically have important roles. Static security control strategies, which deal with the steady state after the contingency is cleared, have been studied by various researchers including the authors. However, the basic research on dynamic security control, which deals with the transient state immediately after the contingency has occurred, is seldom found. This paper presents a method of dynamic preventive control for the transient stability considering plural contingencies collectively and coordinating the requirements from both security and economy flexibly.

In the preventive control for the transident stability, it is necessary to judge the transient behaviors properly and also evaluate the security quantitatively for a postulated contingency. The authors define a security index which represents absorbing capacity of post-fault kinetic energy based on the energy function method. The index has several advantages of being possible to calculate the values fast, being easy to understand its physical meanings, etc. The effectiveness of the proposed method is ascertained through numerical examples for model power systems.

キーワード: 電力系統, 過渡安定度, 予防制御, エネルギー関数法

\section{1. まえがき}

近年の電力系統の大規模複雑化扝上び社会の電力へ の依存度の増加に伴い, 電力系統運用に扔けるセキュ リティ監視制御機能の充実がますます重要となってき ている。しかし現状では, 主としてオンラインセキュ リティ監視機能の実用化にとどまっており，総合的な システムとして監視と制御とを一体化するまでには至 つていないように思われる。このような問題意識の下 で, 著者らは総合セキュリティ監視制御 (ISMAC)
システムを構想し ${ }^{(1)}$ ，開発を進めている。このシステ ムでは，基本的には，高精度で収集されたオンライン データに基づき, 系統内の不測の事故を想定して，常 時から (例光ば, $20 \sim 30$ 分ごと) 予防制御が実施さ れる。また，この予防制御では対処できないような過 酷事故に対しては，その緊急制御方策を個別に計算し 記憶しておき，奏際にそのような過酷事故が発生した ときには，直ちにその制御を実行する。具体的な被制 御項目として注, 潮流, 電圧, 周波数, 安定度など, 様々なものが考えられるが，それらは事故除去後の定 
常状態に扔ける静的なもの（潮流, 電圧, 定態安定度 など）と事故直後の過渡状態における動的なもの（周 波数，過渡・中間領域安定度など）とに大別すること ができる。著者らは，その各々に対し基本となる制御 論理を確立すると共に，将来的にはこれらを統合化 し，本システムをより有用なものとする必要があると 考えている。

静的項目を対象とする制衙に関しては，その基本的 な概念やアルゴリズムが各方面で既に検討されてきて 抢り(2)，著者らも $\mathrm{PQ}$ 分離に基づく予防扝よび緊急制 御の一手法を提案している年(4)。一方, 動的項目を対 象とする制御に関しては，高速な安定化対策を実現す る緊急制御手法の報告はなされているものの ${ }^{(5)}$ ，予防 制御, 特に過渡安定度を対象としたものは, 現在まで

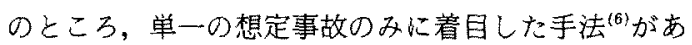
るに過ぎない。常時行われる予防制御に扔いては，い かなる不測の事故発生に対しても系統が安定であるよ うに制御することが望ましく，また完全な安定化が困 難な場合でも，变心ての想定事故を考慮して系統全体 をできるだけ安全側へ移行させておくことが必要であ る。しかし，事故の発生はそう頻繁记起こるものでは ないから，経済性をも同時に評価しつつ方策を決定す べきである。以上のことから本論文では, 複数の想定 事故を一括して考慮でき, 更に経済性との協調も柔軟 に行い得る過渡安定度予防制御手法を提案する。

ところで，過看安定度予防制御においては，予想さ れる事故発生に対して系統が安定であるか否かを適切 に判定し, その安全性の度合を定量的に評価する(七 キュリティ評価）ことが必要である。また複数の事故 を考慮する場合には, 演算の高速性も要求される。本 論文では，エネルギ一関数法の考方方 (7) (9) とし，事故除去後に扝ける運動エネルギ一の吸収能力 に着目したセキュリティ評価指標を提案する。この指 標は高速に計算可能であると共に，指標自体のもつ物 理的意味が明確であるなどの特長を有しているため, オンラインでの過渡安定度予防制御に扔いて有効な指 標と考えられる。

以下，本論女では，第 2 章においてエネルギ一関数 法に基づくセキュリティ評価指標を定義し, 第 3 章で この指標を用いた過渡安定度予防制御問題の定式化と 最適化のための具体的なアルゴリズムについて述ベ る。第 4 章では，重大事故をあらかじめ選択して扔く ことにより，予防制御計算の高速化を図る手法につい て説明する。第5章ではモデル系統を用いた数值例に よって本手法の理解を深めると共に，手法の実用可能 性について検証する。

\section{2. エネルギー関数法に基づくセキュリティ 評価指標}

電力系統の予防制御は，系統内で発生した事故がで きるだけ他へ波及しないように，あらかじめ系統状態 を安全側へ移行させておくものである。従って, 系統 のある運転点が予想される事故発生に対してどの程度 望ましい運転点である加を, 過渡安定度の面から総合 的かつ定量的に評価する(セキュリティ評価)こと が必要となる。また，本論文の予防制御のように複数 の事故を考慮する場合に注, 演算の高速性も要求さ れる。

このセキュリティ一評価に関しては，既に二次元の 特徵空間を用いたパターン認識による手法が検討され ている(6)が，オフラインサンプルを求める際に膨大な 計算量を必要とするなど, 実用化に西たってはいくつ かの問題点を残している。一方, エネルギー関数を用 いて, 系統の安定性が維持され得る最大の事故継続時 間，すなわち臨界故障除去時間を高速に計算する手法 も開発されている(7) (9)。本論文では，このエネルギ 一関数法の考え方をべースとしたセキュリティ評価 を行う。その場合の具体的な評価指標としては, 単に 臨界故障除去時間を用いることも考えられるが，ここ では事故除去時の運動エネルギーと臨界故障除去時の それとの差による新しい指標を定義する。この指標 は, 不安定な事故の場合に, 事故除去後に系統が吸収 できない余分な運動エネルギーを表しており，指標自 体のもつ物理的意味が把握しやすいという利点をも つ。また，制卸変数（具体的には発電機出力）の変化 に対して滑らかであり，その感度も比較的容易に計算 できるという特長ももっている。以下では，文献(9) で提案されている高速な臨界故障除去時間の計算方法 を簡単に説明すると共に，それに基づく具体的なセキ ュリティ評価指標の定義安行う。

〈2・1〉臨界故障除去時間の計算文献(9)に扔 いては，付録 1 に示すような系の定式化とエネルギー 関数に基づき，以下のステップで蜎界故障除去時間を 計算する手法が提案されている。
(1) ステップ 1
（付 3 )式を用いて事故軌跡に 沿ってポテンシャルエネルギー $\left(V_{p}\right)$ と運動エネルギ 一 $\left(V_{k}\right)$ 娄計算する。

（2）ステップ $2 \quad V_{p}$ が極大となったとき，を の $V_{p}$ を臨界エネルギー $V_{p \max }$ とする。

(3) ステップ $3 \quad V_{p \max }=V\left(t_{c r}\right)$ となる $t_{c r}$ を 探し、これを臨界故障除去時間とする。

このように文献（9）の手法では，事故軌跡に沿った 
一回の微分方程式の計算で臨界故障除去時間を求める ことができ，またその精度も実用上十分であることが 確かめられている。ここで注意しなければならないこ とは，この手法は事故除去後の第一波動摇に対する安 定性を解析するものであるということである。過渡領 域の安定度は, 通常数秒程度の間の動摇を対象とし, 䗅密には発電機の飽和や負荷の特性などをも考慮した 詳細な解析が必要と考えられる。本論文では，第一波 動摇で安定ならば，その後は制御器などの効果が期待 でるので安定化可能であろうと仮定し，第一波動摇 のみを掫制するための予防制缻を考えている。

〈2・2〉セキュリティ評価指標の定義＼cjkstart本論文で は，次式のようなセキュリテ評洒指標を提案する。

$$
\begin{aligned}
& S I=\sum_{j=1}^{N C} W_{j}\left(V_{k c j}-V_{k c r j}\right)^{2} \\
& W_{j}=\left\{\begin{array}{l}
0 ; t_{c j} \leqq t_{c r j} \\
\alpha_{j} ; t_{c j}>t_{c r j}
\end{array} \quad \ldots \ldots . .\right.
\end{aligned}
$$

ここで，V $V_{k c}$ は事故除去時 $\left(t_{c}\right)$ の運動エネルギーすな わち事故継続中に発電機に蓄えられる運動工ネルギー を表している。また， $V_{k C r}$ は臨界故障除去時の運動 エネルギー，すなわち事故除去後に系統が吸収し得る 最大の運動エネルギーを表している。これら二つの值 は, 各々前節のステップ1で計算し格納されている値 を取出してくればよい。 $\alpha_{j}$ は，オフラインで経験的 に決定される重みであるが，通常は1.0に設定する。 更に, NC は想定事故の総数である。

この指標は，むべての想定事故に対して安定であれ ば0で，そうでないときは，不安定な事故の除去後に 吸収できずに残る余剩運動エネルギーの2 乗和を表す ことになる。すなわち，余剩運動エネルギーの大きさ により系統のセキュりティを評洒していることにな る。不安定になると予想される事故が実際に発生した 場合には，脱調に至らないよう直ちに何らかの繄急制 御を施すことが必要であるが，その際にはこのような 余剩運動エネルギーが発生しないような，あるいはそ れを吸収させ得るような方策をとるのが一般的であ る(10)。従って, 不安定であっても余剩運動エネルギ 一が小さいほど事故後の緊急制御が容易となり，安全 性嵪い状態と考えられる。ただし, 同じ余剩運動工 ネルギー量を持っている事故でも，例えばその発生地 点により緊急制御の容易さあるいは事故の起こりやす さなどが異なることが経験的に知られている場合に 纯、事故ごとに $\alpha_{j}$ を適当な值に設定しこれを考慮す ることができる。

また 2 乗和の形で定式化しているのは，余鄱運動工
ネルギーの大きな事故，すなわち毉急制御を施しても 脱調に至るような過酷事故を、たとえ他の事故に対す るセキュリティが多少悪化するようになっても，強く 抑制しようという考えに基づくものである。

\section{3. 提案する過渡安定度予防制御アルゴリズム}

〈3.1〉 過渡安定度予防制御問題の定式化常時 の予防制御では，発生した場合の影響は大きいが発生 確率の比較的小さい事故を対象としているため，経済 性を全く無視して制御安実施することは得策ではな い。徒って, 過渡安定度予防制御問題は, 経済性を考 慮に入れたうえで，系統ができるだけ安定となるよう なつまり前章で定義したセキュリティ評価指標がで きるだけ小さくなるような火力発電機の制御量を決定 する問題として記述できる。

経济性と過渡安定度という，いわ代翼質ともみなせ る目整の協調を図る方法としては，主として二つの考 え方がある(1)。一つは，いずれか一方の目標（例え ば，過渡安定度）をある望ましいレベル内に保つとい う制䄪条件の下で，残りの目標を最大限追求する考之 方である。他の一つは，両方の目標をある重みづけを 行うことにより一つの評価関数にまとめ，これを最適 化する考文方である。本論文においては後者を採用す る。こ扎は，前者の力法では系統規模り増大に伴い想 定事故の数が增し，制約条件を満足するような解が存 在しない可能性が大きくなるためである。

従って，セキュリティ指標に運用コストを加え，次 式のような目的関数 $(P I)$ を定義する。

$$
P I=p_{c} C+S I
$$

ここで，Cは電力系統内の発電機の総燃料費である。 また p とるための重み係数を表している。ただ，この具体 的な倌は，系統規模や運用状態などを十分考慮し，詳 細なオフライン計算などから，いわば経験的に決定し なければならない。その場合，一つの方針として，重 負荷，中負荷，軽負荷に相当する $p_{c}$ の值をそれぞれ 用意し，状況に応じて切換え使用するち法が考えられ よう。

(3)式の目的関数を種々の制約条件の下で制御変数 に関して最小化し，最適な予防制御量が算出される。 制御可能な変数としては，一般に発電機出力の指定值 や発電機の端子電圧など, 種々のパラメータが考えら れるが，本論文ではこのうち效果が大きいと考えられ る発電機出力 (=事故前の機械的入力) に注目し, こ れを制御変数とする。つまり，予防制郝問題を次の上 
うな非線形最適化問題として定式化する。

$\min \operatorname{PI}\left(\boldsymbol{P}_{m}\right)$

subj. to $h\left(\boldsymbol{P}_{m}\right)=0$

$\boldsymbol{P}_{m \min } \leqq \boldsymbol{P}_{m} \leqq \boldsymbol{P}_{m \text { max }}$

ただし， $h=0$ は事故前の状態すなわち平常状態にお ける需給平衡条件を表している。また， $\boldsymbol{P}_{m}$ は平常状 態の発電機出力ベクトルで, $\min , \max$ は各々下限扝 よび上限を意味している。

〈3.2〉 最適化手法 前節で定式化した問題を適 当な数理計画法を用いて最小化する。ここで，運用コ スト $(C)$ やキュリティ指標 $(S I)$ 注制御変数の変化 に対して滑らかな関数であるため，最小化に際しては 通常の微分可能な関数に対する最適化手法をそのまま 適用できる。本論文では，アルゴリズムが簡単でしか も大域的収束性が保証されている最急降下法を採用す ることとしたが，その場合の具体的な最適化アルゴリ ズムは次のとおりである。

(1) ステップ1〈2・1〉節のアルゴリズムにし たがつて高速に $V_{k c r}, V_{k c}$ を計算し，PI の值を求め, 繰返し回数を表すインデックス $l$ を 1 とおく。

（2）ステップ 2 PI の各発電機出力(スラッ ク発電機を除く)に関するこう配 $D P I$ を計算する。 この具体的な計算方法については次節で説明する。

（3）ステップ3次式に従って発電機出力の值 を更新する。

$$
\boldsymbol{P}_{m}^{\prime l}=\boldsymbol{P}_{m}^{\prime l-1}-\beta(C P I)^{T}
$$

ただし，及はステップ2で求められたこう配に括い て, $P I$ を発電機出力の上下限制約内で最小とする值

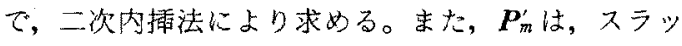
ク発電機を除いた発電機出力ベクトルを表している。

(4) ステップ4 $\boldsymbol{P}_{m}^{\prime l}$ を用いて潮流計算を行 い, 更に $V_{k c r}, V_{k c}$ を計算し, $P I\left(\boldsymbol{P}_{m}^{l}\right)$ の值を求める。 このように，発電機出力を更新するごとに潮流計算を 実行すれ代平常状態の需給平衡条件が満足される。

（5）ステップ 5 収束判定条件：

$$
\left|P I\left(\boldsymbol{P}_{m}^{l}\right)-P I\left(\boldsymbol{P}_{m}^{l-1}\right)\right|<\varepsilon^{*}
$$

を満足していれば終了。そうでなりれば $l=l+1$ とし てステップ2へ戻る。ただし，とは十分小さな正の值 である。

また，スラック発電機出力に対する制約は，その制 約逸脱量という形で目的関数に加えた拡張目的関数を 導入し，それに付加されている重みを徐々に増加させ ていくことによって満足させる。

$\langle 3 \cdot 3\rangle こ j$ 配の計算 目的関数の発電機出力に 関するこう配は次式で表現される。

$$
\frac{d P I}{d \boldsymbol{P}_{m}^{\prime}}=\frac{\partial P I}{\partial \boldsymbol{P}_{m}^{\prime}}+\frac{\partial P I}{\partial P_{m s}} \frac{d P_{m s}}{d \boldsymbol{P}_{m}^{\prime}}
$$

ただし， $P_{m s}$ はスラック発電機の出力を表している。 ここで, $\left[d P_{m s} / d \boldsymbol{P}_{m}^{\prime}\right]$ は潮流計算用に構成されている $P Q$ 分離線形モデルと相反定理の考え方を適用するこ とによって高速に計算される(文献（3)参照)。従っ て，(9)式の計算に扔いては， $\left\{\partial P I / \partial P_{m}^{\prime}\right]$ ( $\left(\partial P I / \partial P_{m s}\right)$ も同様) を如何にして求めるかというこ とが問題となる。説明を簡単にするため，この項の $i$ 番目の発電機に関する要素のみを取出し，更に(1) ～( 3 ) 式の関係を用いると以下のように表される。

$$
\begin{aligned}
\frac{\partial P I}{\partial P_{m i}^{\prime}}= & p_{c} \frac{\partial C}{\partial P_{m i}^{\prime}}+2 \sum_{j=1}^{N C} W_{j}\left(V_{k c j}-V_{k c r j}\right) \\
& \times\left(\frac{\partial V_{k c j}}{\partial P_{m i}^{\prime}}-\frac{\partial V_{k c r j}}{\partial P_{m i}^{\prime}}\right) \ldots \ldots \ldots \ldots . . .
\end{aligned}
$$

右迅第 1 項の值蛙，Cの関数形が具体的に与えられ ると容易に計算できる。また第 2 項も，適当な近似を 行えば，偏微分の項が次式のように比較的簡単な代数 演算形となるため(具体的な導出過程を付録 2 に示 す)，その值を高速に計算することが可能である。

$$
\frac{\partial V_{k j}}{\partial P_{m i}^{\prime}}=\left\{\frac{P_{m i}^{\prime}-P_{e i j}}{M_{i}}-\frac{\sum_{i=1}^{n}\left(P_{m i}-P_{e i j}\right)}{M_{T}}\right\} t^{2}
$$

上式に捛いて, $t$ は事故発生時点からの時刻を表して いる。従って, $t=t_{c j}$ のとき, $V_{k j}$ は $V_{k c j} に, t=t_{c r j}$ のとき， $V_{k j}$ は $V_{k c r j}$ に対応する。

\section{4. 重大事故選択による予防制御計算の高速化}

前章で述べた予防制御アルゴリズムでは，目的関数 の值を求める際，すべての想定事故に対して臨界故障 除去時間を計算することが必要であった。この計算は 各事故ごとに微分方程式を解くため，系統規模の増大 に伴い膨大な計算時間になると予想される。一方, (2)式加らかかるように, 安定な事故に対しては重み

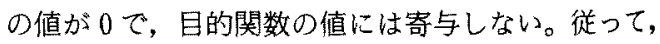
事故発生に対して系の安定度か゚十分維持されると予想 される事故は, 最適化の過程で制御变数を更新するご とに逐一臨界故障除去時間を計算しなくてもよいと考 えられる。

本章では，この考えに基づき本アルゴリズムの高速 化を図る手法について説明する。

〈4・1〉 重大事故の選択 ${ }^{(12)}$ 臨界故障除去時間の 計算を必要とする事故（重大事故と呼ぶ）を適切に選 択するため, 全想定事故をその臨界故障除去時間によ つて安全，警戒，危険の三つの集合に分類する。ただ 
し，各集合は次式のように定義される。

$$
\left.\begin{array}{lll}
t_{c}^{\prime}<t_{c r} & \cdots & \text { 安全集合 } \\
t_{c} \leqq t_{c r}<t_{c}^{\prime} & \cdots & \text { 警戒集合 } \\
t_{c r} \leqq t_{c} & \cdots & \text { 危険集合 }
\end{array}\right\}
$$

ここで，襣は次式により計算する。

$$
t_{\mathrm{c}}^{\prime}=\gamma t_{\mathrm{c}}
$$

ただし， $\gamma$ は 1より大きい正の数である。

（12）式から明らかなように，制御前に警戒集合に属 している事故は，一応安定ではあるが危険集合に比較 的近く，制御による系統状態の変化に伴い，危険集合 内に移行する可能性を無視できない。従って, 重大事 故としては，制御前の系統状態で危険集合内にある事 故怡もちろん，警戒集合内にある事故をも選択するこ とが望ましいと考えられる。また， $\gamma$ の值を適当に調 整することによって，どの程度までを警戒集合とする かというオぺレータの意図を反映させることがで きる。

$\langle 4-2\rangle$ 予防制御計算の高速化手法 前節の重大 事故選択に基づき，以下に述べるようなアルゴリズム で予防制御計算の高速化を図る。まず，予防制御を施 す前の初期状態で，全想定事故に対して臨界故障除去 時間を計算し，重大事故を選択する。次に，第 3 章の アルゴリズムに従い，選択された事故のみを対象とし て(4)〜(6)式を解く。得られた解に対して無視した 事故の安全性をチェックし，それらがすべて安定であ るならば計算を終了する。そうでなければ，再び重大 事故の選択を行い同様の操作を繰返す。ただし，新た

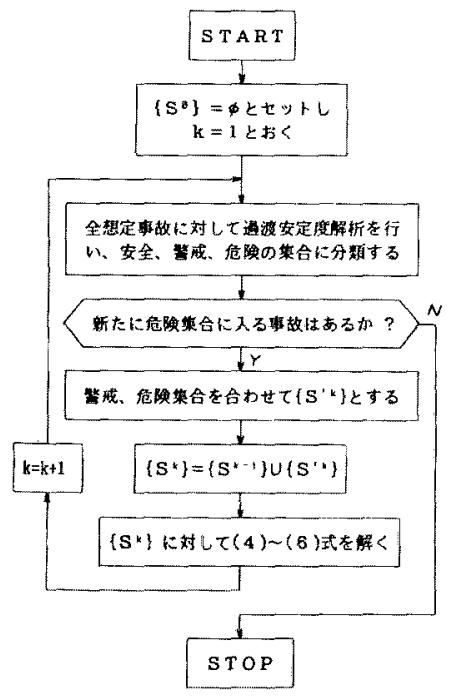

図 1 予防制御の高速化アルゴリズム

Fig. 1. An algorithm for the fast preventive control calculation.
な重大事故の集合は前に選択されていた事故をも含め るように構成する。このようにすれば，最悪の場合で も全部の事故を選択した段階で，計算が終了すること になる。以上のアルゴリズムの全体の流れを図 1 に 示す。

もっとも，この手順を繰返していっても必ず高速に 解が得られるという保証はなく，上記のように全部の 想定事故を考慮せ朴ばならないこともあり得る。どの 程度計算の手間が省けるかは，あらかじめ知ることは できないが，常時から予防制御による運用が行われて いる場合は，制御による系統状態の変化好それほど大 きくはなく，かなりの効果が期待できるものと考えら れる。

\section{5. 数 值 例}

提案した手法の有効性を検証するため，図 2 に示す ような CIGRE 7機 10 母線系統(13)を用いてシミュレ ーションを行った。想定事故としては，極めて過酷で ある母線近傍に扮ける送電線の三相地絡故障を考え る。また，本シミュレーションではすべての想定事故 に対して故障発生後，0.12秒で事故が除去されるも のと仮定する。表 1 は各想定事故に対する臨界故障除 去時間と余剩運動エネルギーを，表 2 はそのときの各 発電機出力の值を示している。ただし，表中の踟界故 障除去時間はシミュレーション法により求めた㦑密な 值である。これらの表において，ケース 1 は最経済で 運用されている初期状態, ‘ース 2 抢よびケース 3 は 各々せキュリティのみを考慮して $\left(p_{c}=0.0\right)$ および セキュリティと経済性とを同時に考慮して $\left(p_{c}=0.03\right)$ 予防制御を行った状態である。また，すべての事故に 対し重み係数 $(\alpha)$ の值を 1.0 とし, 更に( 8$)$ 式の収束 判定定数 $(\varepsilon)$ 扔よび (13)式の係数 $(\gamma)$ を各々 0.01 およ び 1.3 と設定した。この表加ら，予防制御を施すこと によって不安定となる事故ゲース（表 1 中の下線部

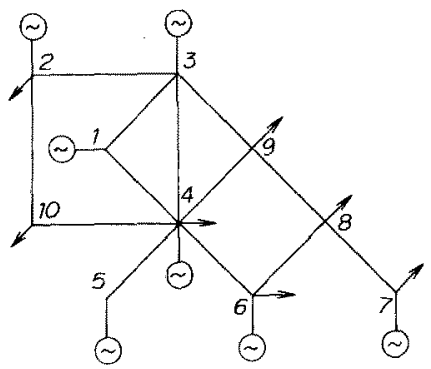

図 2 CIGRE 7 機系統

Fig. 2. 7 machine CIGRE test system. 
表 1 予防制御の結果

Table 1. Results of preventive control.

\begin{tabular}{|c|c|c|c|}
\hline \multirow{2}{*}{$\begin{array}{c}\text { 事故ケーメ } \\
i-j\end{array}$} & \multicolumn{3}{|c|}{ 臨界故障除去時間（秒） } \\
\hline & $5-x 1$ & ケーx.2 & ケース3 \\
\hline $1 *-3$ & $0.09(2.84)$ & $0.13(-)$ & $0.11(0.80)$ \\
\hline $1-3 *$ & $0.21(-)$ & $0.32(-)$ & $\overline{0.27}(-)$ \\
\hline $1 *-4$ & $0.09(2.84)$ & $0.12(-)$ & $0.11(0.80)$ \\
\hline $1-4 *$ & $0.20(-)$ & $0.33(-)$ & $0.26(-)$ \\
\hline $2 *-3$ & $0.33(-)$ & $0.26(-)$ & $0.29(-)$ \\
\hline $2-3 *$ & $0.22(-)$ & $0.32(-)$ & $0.27(-)$ \\
\hline $2 *-10$ & $0.33(-)$ & $0.26(-)$ & $0.29(-)$ \\
\hline $3 *-4$ & $0.22(-)$ & $0.32(-)$ & $0.27(-)$ \\
\hline $3-4 *$ & $0.20(-)$ & $0.34(-)$ & $0.27(-)$ \\
\hline $3 *-9$ & $0.22(-)$ & $0.32(-)$ & $0.28(-)$ \\
\hline $4 *-5$ & $0.21(-)$ & $0.33(-)$ & $0.27(-)$ \\
\hline $4-5 *$ & $0.23(-)$ & $0.20(-)$ & $0.21(-)$ \\
\hline $4 *-6$ & $0.21(-)$ & $0.34(-)$ & $0.27(-)$ \\
\hline $4 *-9$ & $0.21(-)$ & $0.34(-)$ & $0.27(-)$ \\
\hline $4 *-10$ & $0.21(-)$ & $0.34(-)$ & $0.27(-)$ \\
\hline $6-8 *$ & $\underline{0.09}(0.80)$ & $0.21(-)$ & $0.16(-)$ \\
\hline $7 *-8$ & $\underline{0.03}(3.98)$ & $0.11(0.36)$ & $\underline{0.08}(1.59)$ \\
\hline $7-8 *$ & $0.05(1.53)$ & $0.19(-)$ & $0.14(-)$ \\
\hline $8 *-9$ & $0.11(0.29)$ & $0.22(-)$ & $0.18(-)$ \\
\hline $\operatorname{cosT}(\$ / h)$ & 9046.9 & 9147.3 & 9085.7 \\
\hline 計算時間（S) & - & 4.0 & 5.2 \\
\hline
\end{tabular}

注)・事故タ一スの $\mathrm{i}-\mathrm{j} に$ に拈る*印は事故母線を示す。

・()内の値は余鄱運動エネルギー(pu) である。

表 2 発電機出力の值

Table 2. Values of generator outputs.

\begin{tabular}{c|c|c|c}
\hline \multirow{2}{*}{$\begin{array}{c}\text { 発電機 } \\
\text { (贯線) } \\
\text { 番号 }\end{array}$} & \multicolumn{3}{|c}{ 発電機出力 (MW) } \\
\cline { 2 - 4 } & ケ-ス1 & ケース 2 & ケース 3 \\
\hline 1 & 798.01 & 653.98 & 717.91 \\
2 & 234.02 & 299.86 & 265.95 \\
3 & 351.02 & 401.84 & 382.85 \\
4 & 390.10 & 449.03 & 426.64 \\
5 & 429.00 & 477.32 & 459.70 \\
6 & 351.02 & 395.90 & 382.44 \\
7 & 626.01 & 480.00 & 529.82 \\
\hline
\end{tabular}

分）の数が滅少し，また不安定であっても余剩運動工 ネルギーが滅少し，セキュリティが向上していること がわかる。また，経済性を考慮すると無視した場合に 比へて不安定となる事故が多少增加するが, 総燃料費 は減少している。つまり，この運用状態は最経済の運 用状態と最安定の運用状態の中間の状態である。図 3 は $p_{c}$ の值によって運用コスト招よび余剩運動エネル ギーがどのように変化するかを示したものである。当 然のことながら， p 0 值が大きくなるにつれて，予 防制御方策は経済性を重視した状態に近づいてくると いう様子がわかる。

更に，図４は重大事故選択に上る効果を示すため,

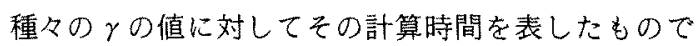

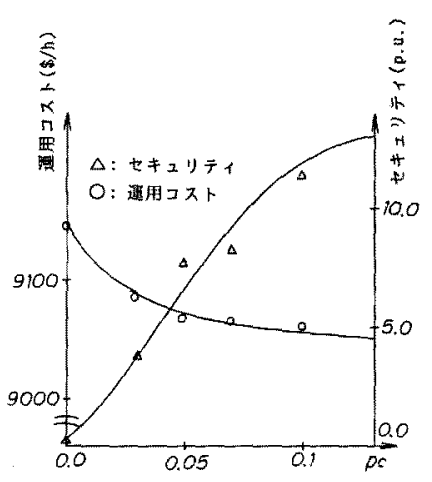

図 $3 p_{c}$ に対する鼠適解の変化

Fig. 3. Optimal solutions versus $p_{c}$.

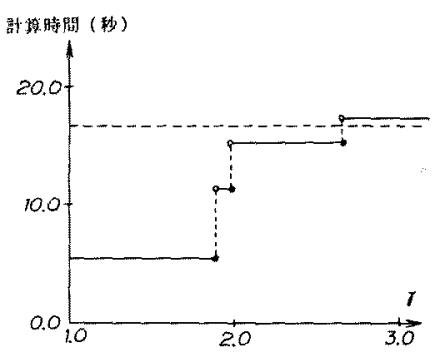

図 $4 \gamma$ に対する計算時間の変化

Fig. 4. Computation time versus $\gamma$.

ある。ただし，いずれも $p_{c}$ の值を 0.03 に設定してお り,その場合の最適解は等しい点に収束している。ま た図中の破線は，最初からすべての想定事故を対象と して計算を行った場合の計算時間を示している。この

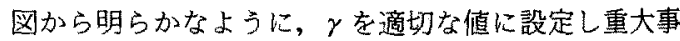
故をあらかじめ選択しておくことによって，大幅に高

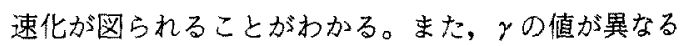
のにもかかわらず計算時間が等しい場合があるのは, 最初の選択で全く同じ事故が選ばれ，しかも2回目の 選択においてどちらも新たに危険集合に入る事故がな く計算を終了したためである。

次に，提案した手法の実規模系統への適用可能性を 評価するために，IEEE 118 母線系統（発電機 18 台, 想定事故 358 ケース）を用いてシミュレーションを行 つた。実運用においては常時から予防制御を実行する ことになるため，制御前の初期点はほとんどの場合， 最適解の近傍に存在していると考えられるが，ここで はセキュリティ改善効果が顕著に現れるよう, 最適解 から比較的離れた最経済運用点を初期状態とした。ま た， p $c, \gamma$ の值をそれぞれ $0.03,1.3$ に設定しな。得 られた結果は，上述の小規模系統に対する結果と大き 
く変わるものではなかった。すなわち，初期状態では 不安定となる事故が9ケース存在していたのに対し， 予防制御を施すことによりすべての事故が安定範囲内 に抑之込末れた。また，重大事故としては最初に26 ケース（危険 9, 警戒 17) が選択されたが，2回目 に泣，新たに危険集合内に入る事故がなかったため計 算を終了した。この場合の計算時間は約 18 分であっ た。上述のように，本シミュレーションでは比較的過 酷な条件を想定しているため，予防制御を仮に 20〜30分ごとに行うものとすれば，この計算時間は 実運用上許容できる範囲内にあるといえよう。

ところで, 計算時間をアルゴリズムの部分ごとに詳 細に㛟討したところ，重大事故選択のための想定事故 の分類抒よび (4)〜 (6)式を解く際の目的関数值の計 算が全体の計算時間の大部分を占めていることが明ら かになった。この計算は主に，すべてのあるいは幾つ かの想定事故に対する臨界故障除去時間の計算であ クここではこれを一事故ずつ順次計算している。し かし, 個々の事故の計算では, 他の事故に対する結果 を待つ必要がないため，適切な並列計算を行えば，更 なる高速化が期待できるものと考えられる。

\section{6.むすび}

本論文では，総合セキュリティ監視制御システム開 発の一環として, 事故後の過渡安定度を対象とした予 防制御手法を提案した。また、モデル係数を用いた数 值例により本手法がオンラインでも十分に機能できる という見通しを得た。提案手法の特長は以下のとおり である。

（1）本論文の予防制御は，事故中に蓄えら机万余 剩運動エネルギーを減少させることを目的としている ため，事故後の安定化制御の容易さという点に扔いて 実際的な方策が得られる。

（2）系統全体のセキュリティ向上を図るために複 数の想定事故を制御対象とし，更に経済性との協調を も考光ている。

（3）重大事故をあらかじめ選択しているので，計 算は効率的かつ高速に実行できる。

本論文では，平常状態に扔ける制約条件として需給 平衡条件捛よび発電機出力の上下限制約のみを考えて いたが，実際に㹥送電線潮流や負荷母線電圧などに関 する上下限制約および定態安定度に関する制約をも考 慮する必要がある。線路潮流などに関する制約は，既 に著者らが提案した静的な被制御項目を対象とする予 防制御手法の中では考慮されており，この考え方をそ のまま適用すれば容易に应張することができる。一
方，定態安定度に関しても，本論文の予防制御が比較 的大きな擾乱に対する過渡安定度を向上させるものと なっていることから，結果的に浪活維持されていると 考えてもよいと思われる。事実, 本シミュレーション では，定態安定度を逸脱するグースはなかった。

ところで, 著者らは, 本手法と並行して, 高速な過 渡安定度判定が可能であるパターン認識者用いた予防 制御の基本的な検討も行っている(14)。過渡安定度予 防制御をより有用なものとするためには，両手法の特 徵を最大限に生かした総合的なアルゴリズムの開発が 必要であると思われる。

最後に，本研究を行うにあたって貴重な御意見をい ただいた北見工業大学山城 迪教授おっび北海道大 学工学部田中英一助手に心から感謝の意を表する次 第である。また，数値計算には北海道大学大型計算機 センターHITAC M-682 H を使用したことを付記し， 関係各位に感謝の意を表する。

(平成元年 11 月 24 日受付)

\section{文献}

(1) J. Hasegawa, E. Tanaka, T. Yamada \& D. J. Li : "Funda. mental Research on Integrated Security Monitoring and Control (ISMAC) Systems", Int. J. Energy Syst., 8. 173 (1988)

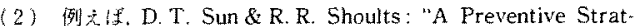
egy Method for Voltage and Reactive Power Dispatch". IEEE Trans. Poncer Apparatus Syst, PAS-104, 1670 (1985)

（3）北・曰中・長谷川：「経济性在考虑したオンライン $P Q$ 分踓 形予防制御手法」，電学諭 B, 108.475 (昭 63-10)

（4）北・田中・西谷・長谷川：「総合七キュリティ監視制御シ ス

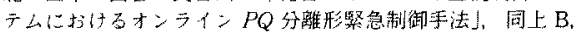
109, 467 (平元 -10$)$

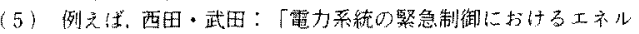
ギー法に基づいた制御望決定アルゴリズム」，同上B、102. $653($ 昭 57-10)

（6）山城・奈良・少池：「バターン認識に上る電力系繶の七キュ りチ亿予防制御」，同上 B, 105, 7 (昭 60-1)

(7) T. Athay, R. Podmore \& S. Virmani; "A Practical Method for the Direct Analysis of Transient Stability", IEEE Trans. Power Apparatus Syst. PAS-98, 573 (1979)

(8) N. Kakimoto, Y. Ohsawa \& M. Hayashi: "Transient Stability Analysis of Electric Power System via Lur'e Type Liapunov Function. Part I. New Critical Value for Transient Stability". Trans., IEE of Japan, 98,63 (1978)

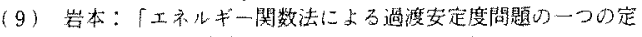

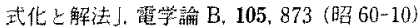

(10) 川烟・木戸：「霆力系統の直列コンデンサ㧍上ざ值列抵抗に 上る遇渡安定度制街」，同上B，99，253(昭 54-4)

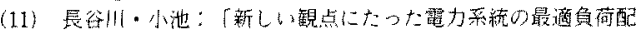
分門題」, 同上 B, 94.241 (昭 49-5)

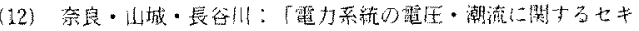

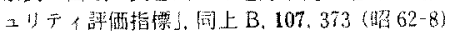

(13) M. A. Pai: Power system stability (1981) North Holland Publishing Company

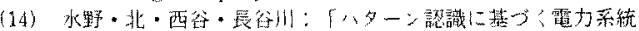

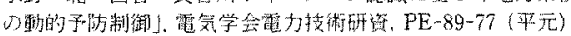




\section{付 録}

\section{1. 系の定式化とエネルギー関数}

Athay らは, 同期平衡という概念から，位相角中 心の座標を用いて，次のような系の定式化とエネルギ 一関数を提案している(7)。

$$
\begin{aligned}
& \dot{\theta}_{i}=\omega_{i} \\
& \dot{\omega}_{i}=M_{i}^{-1}\left(P_{m i}-P_{e i}-R_{i} P_{c o a}\right)
\end{aligned}
$$

ただし， $P_{c o a}=\sum_{i=1}^{n}\left(P_{m i}-P_{e i}\right):$ 総電力ミスマ ッチ, $M_{T}=\sum_{i=1}^{n} M_{i}, R_{i}=M_{i} / M_{T}, \theta_{i}:$ 第 $i$ 発電 機の位相角中心系汸汀る内部電圧の位相 角, $\omega_{i}$ : 第 $i$ 発電機の位相角中心における角 速度, $M_{i}$ : 第 $i$ 発電機の慣性定数, $R_{i}$ : 第 $i$ 発電機のミスマッチ振り分讨定数, $P_{m i}$ : 第 $i$ 発電機の機械的入力 $(=$ 事故前の発電機出 力), $P_{e i}:$ 第 $i$ 発電機の電気的出力, $n:$ 発 電機総数

この定式化に基づくエネルギー関数は次式となる。

$$
\begin{aligned}
V= & \frac{1}{2} \sum_{i=1}^{n} M_{i} \omega_{i}^{2}-\sum_{i=1}^{n} P_{i}\left(\theta_{i}-\theta_{i}^{s}\right) \\
& -\sum_{i=1}^{n-1} \sum_{j=i+1}^{n} B_{i j} E_{i} E_{j}\left(\cos \theta_{i j}-\cos \theta_{i j}^{s}\right) \\
& +\sum_{i=1}^{n-1} \sum_{j=i+1}^{n} \int_{\theta_{i} s+\theta_{j} s}^{\theta_{i}+\theta_{j}} G_{i j} E_{i} E_{j} \cos \theta_{i j} d\left(\theta_{i}+\theta_{j}\right)
\end{aligned}
$$

ただし， $E_{i}$ : 第 $i$ 発電機の内部電压の大き

さ, $\theta_{i}^{s}:$ 安定平衡点での $\theta_{i}, \theta_{i j}=\theta_{i}-\theta_{j}, Y_{i j}$ $=G_{i j}+j B_{i j}:$ 縮小アドミタンス行列の $(i, j)$

要素, $P_{i}=P_{m i}-G_{i i} E_{i}^{2}$

(付 3 )式において第 1 項が運動エネルギー $\left(V_{k}\right) て ゙$, 第 2 項以下がポテンシャルエネルギー $\left(V_{\rho}\right)$ である。

\section{2.（11)式の導出}

まず，事故除去までの短時間であれば事故中の加速 電力はほほ一定と考元てもよいので(5), 事故 $j$ におけ るある時点 $t$ の角速度 $\omega_{i j}$ は(付 2 ) 式より,

$$
\omega_{i j}=\frac{P_{m i}-P_{e i j}-R_{i} P_{c o a j}}{M_{i}} t
$$

となる。ただし， $P_{e i j} や P_{c o a j}$ は，ともに事故発生時 の值である。ゆえに, 運動エネルギー $V_{k j}$ は,

$$
V_{k j}=\sum_{i=1}^{n} \frac{1}{2} M_{i} \omega_{i j}^{2}
$$

$$
\begin{aligned}
= & \sum_{i=1}^{n} \frac{1}{2} \frac{\left(P_{m i}-P_{e i j}\right)^{2}}{M_{i}} t^{2} \\
& -\frac{1}{2} \frac{\left\{\sum_{i=1}^{n}\left(P_{m i}-P_{e i j}\right)\right\}^{2}}{M_{T}} t^{2}
\end{aligned}
$$

となる。このとき, $P_{m i}^{\prime}$ の微小変化に対する $P_{e i j}$ や $t_{c r j}$ の変化は比較的小さいと考えられるため, これを 0 と仮定すると，運動エネルギーのこう配は(11)式と なる。

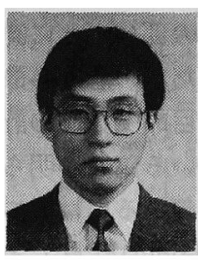

\section{北裕 幸（正員）}

昭和 38 年 5 月 7 日生。 63 年 3 月 北海道大学大学院工学研究科電気工 学専攻修士課程修了。同年 4 月同博 士課程進学。平成元年 4 月同大学工 学部電気工学科助手となり, 現在に至る。主として, 電力系統の解析・制御に関する研究に従事。

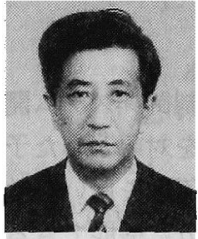

西 谷 健 一 (正員)

昭和 22 年 2 月 11 日生。 44 年 3 月北海道大学理学部物理学科卒業。 同年 4 月同大学工学部電気工学科助 手，同講師を経て，平成元年 4 月同 助教授, 現在に至る。電力系統工学, 特に電力系統の 状態推定, 解析おるひび運用・計画に関する研究に従事。 工学博士。システム制御情報学会会員。

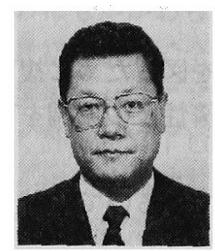

\section{長谷川＼cjkstart淳（正員）}

昭和 18 年 12 月 13 日生。 46 年 3 月北海道大学大学院工学研究科電気 工学専攻博士課程修了。同年 4 月同 大学工学部講師, 同助授を経て, 60 年 4 月同教授, 現在に至る。主として, 電力系統の計 画・運用・制御・解析，およぴエネルギー貯蔵に関す る研究に従事。工学博士。日本 OR 学会, IEEE 会員。 